\title{
CULTURAL INDUSTRIES IN THE DEVELOPMENT POLICIES OF CITIES AND REGIONS: A NEW AREA OF EDUCATION IN SPATIAL MANAGEMENT
}

\author{
Pawee Churski, Pawee Motek, Tadeusz Stryjakiewicz \\ Institute of Socio-Economic Geography and Spatial Management, Adam Mickiewicz University in Poznań, \\ Poland
}

Manuscript received: December 2, 2014

Revised version: March 31, 2015

\begin{abstract}
Churski P., Motek P., Stryjakiewicz T., 2015. Cultural industries in the development policies of cities and regions: A new area of education in spatial management. Quaestiones Geographicae 34(2), Bogucki Wydawnictwo Naukowe, Poznań, pp. 87-97, 1 fig. DOI 10.1515/quageo-2015-0018, ISSN 0137-477X.

AвSTRACT: This paper seeks to present organisational and programme assumptions of a new field of postgraduate studies called Cultural industries in the development policies of cities and regions, prepared by a team of workers of the Institute of Socio-Economic Geography and Spatial Management of Adam Mickiewicz University in Poznań as a didactic innovation based on a modular system of education that meets contemporary changes in the labour market. The analysis will also embrace experiences following from the educational process implemented under the Human Capital Operational Programme in the years 2013-2015 (Priority IV: Tertiary Education and Science, Measure 4.3: Enhancing the didactic potential of universities in areas of key importance for the Europe 2020 Strategy). They provide a basis for conclusions and recommendations for higher schools interested in the development of this area of education.
\end{abstract}

KEY wORDS: spatial management, cultural industries, development policy, teaching, postgraduate study, modular syllabus, quality of education

Pawet Churski, Pawet Motek, Tadeusz Stryjakiewicz, Institute of Socio-Economic Geography and Spatial Management, Adam Mickiewicz University, Dzięgielowa 27, 61-680 Poznań,Poland; e-mail: chur@amu.edu.pl, pamo@amu.edu.pl, tadek@amu.edu.pl

\section{Introduction}

The highly dynamic changes in the modern economy and society give rise to new, so far unknown, challenges for the development policies of towns and regions, which in turn makes it necessary to educate a body of specialists able to meet those challenges. The changes introduced in the legal foundations of the higher-level educational system in Poland, like the implementation of the National Qualifications Framework (NQF) resting on the idea of education intended to bring effects in knowledge, skills and competence, allow making broad changes in this system. Among the elements of the organisation of the new system are modules. A modular system of education offers a chance of improving the quality of the teaching process in each field and at every level of study. Its advantages, however, can best be used in an interdisciplinary type of study. An example of such a field of study is Spatial Management and its specialisations, which include cultural industries in the development policies of towns and regions (Churski 2013).

This paper seeks to present the organisational and programme assumptions of a new field of postgraduate studies called Cultural industries in the development policies of cities and regions, worked out by the staff of the Institute of Socio-Economic Geography and Spatial Management of Adam 
Mickiewicz University (AMU) in Poznań as a didactic innovation based on a modular system of education that meets contemporary changes in the labour market (Churski, Motek 2013). The analysis will also embrace experiences following from the educational process implemented in the years 2013-2015 under the Human Capital Operational Programme (Priority IV: Tertiary Education and Science, Measure 4.3: Enhancing the didactic potential of universities in areas of key importance for the Europe 2020 Strategy). They allow formulating conclusions and recommendations for higher schools interested in the development of this area of education.

\section{Cultural industries in the development policies of towns and regions}

Cultural industries are among the most significant characteristics of changes taking place in the economy and society of today. They determine a new paradigm of regional and local development that can be summed up in the statement that preparing good conditions capable of attracting creative people and types of activity (including cultural industries) has become equally, if not more, important as creating jobs in the traditional industries (Stryjakiewicz 2011). The essence of those changes is the difference between the development paths of towns and regions in the traditional and the new economy (cf. Fig. 1). A quotation from Boschma and Fritsch (2009: 244) captures it best: the new conceptions "place emphasis on the socio-cultural underpin-

Traditional concepts

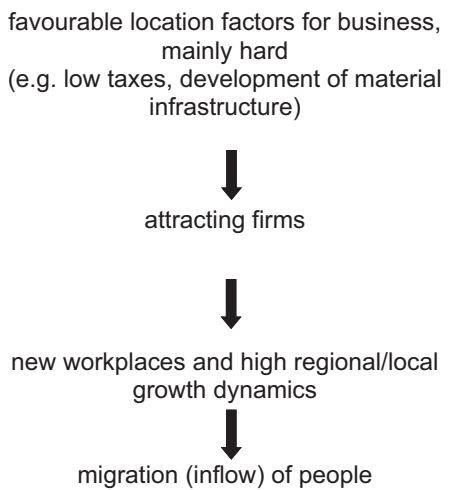

nings of regional development". The resulting "good 'people's climate' provides a conducive environment for regional growth. This stands in contrast to conventional beliefs that refer to qualities of places in terms of 'business climate', such as low taxes or a rich supply of physical infrastructure". But "the essence of this proposition is that places with a good 'people's climate' retain and attract creative people who, in turn, induce new economic activities, such as start-ups and high-tech firms. Therefore, the creative class is not attracted to places with high growth per se. On the contrary, regional growth is expected to be more of an outcome of the presence of creative people, or in the terminology of Florida, jobs will follow people instead of people following jobs."

In the case of Poland, the development of the so-called creative sector (which embraces cultural industries) acquires special importance because it can be one of the factors stemming the outflow of young, well-educated and talented people abroad. However, the awareness of the need to support the development path described above is still too poor, both among politicians and decision-makers and in society. This change in awareness - on the one hand, by popularising good examples of the impact of cultural industries on the development of towns and regions, and on the other, by the formation of the knowledge and skills of decision-makers responsible for this development - is one of the most important reasons for the offer of the postgraduate studies presented in this article.

The term 'cultural industry' was coined in the late 1940s by two sociologists: Theodor Adorno

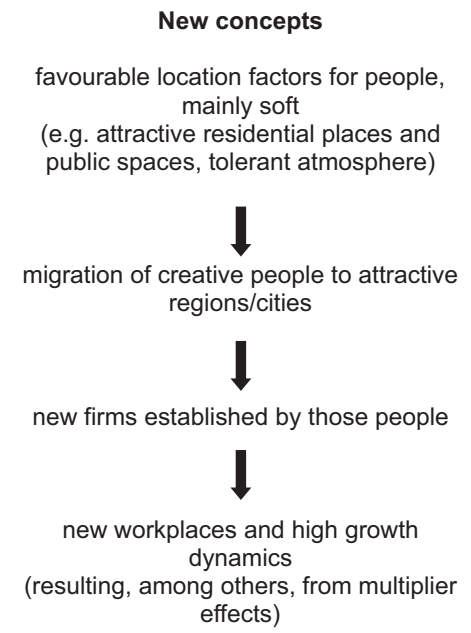

Fig. 1. Development paths of towns and regions in the traditional and the new economy. Source: Stryjakiewicz (2010). 
and Max Horkheimer. At that time it had pejorative implications and meant depriving products of art of their artistic value and reducing them to a commercial value only. Today this term has altered its meaning and is variously defined in individual countries. For example, in The Netherlands it usually denotes the kinds of economic activity associated with authors' rights; Germans use it in the meaning of a cultural economy (Kulturwirtschaft), while the British often combine cultural industries together with creative ones. In the Polish language, 'cultural industries' is not a well-founded notion. Its appearance is a consequence of a direct translation of the English word 'industry' (which has a broader semantic scope than Polish 'przemysł' and denotes every kind of non-agricultural economic activity). Perhaps the English 'cultural industries' would have been better translated as 'activities in the field of culture'; still, this term has already gained much popularity both in scientific literature (e.g. Klasik 2010) and in regional-policy documents. For this reason it has also been used in the name of the postgraduate studies discussed here.

The definition of cultural industries worked out by UNESCO at a 1982 forum in Montreal describes them as activities involving large-scale production, reproduction, storage and distribution of cultural goods and services. A more recent definition (the late 1990s), proposed by Great Britain's Department for Culture, Media and Sport, describes them as those activities which have their origin in individual creativity, skill and talent, with a potential for job and wealth creation through the generation and exploitation of intellectual property. Thus, cultural industries include:

- artistic activities and crafts,

- conservation of monuments and works of art,

- art galleries and trade in artwork,

- performing arts,

- film, video and audio-visual production,

- music,

- publishing,

- media (television, radio, press, the Internet),

- advertising,

- graphic and industrial design,

- designer fashion and interior design,

- architecture, and

- computer games and software.
In Poland, the present development level of cultural industries (and more broadly, of the creative sector) is far from satisfactory. This is illustrated, among other things, by the results of the international research project ACRE (Accommodating Creative Knowledge - Competitiveness of European Metropolitan Regions within the Enlarged Union), implemented within the Sixth Framework Programme of the European Union with the participation of the Institute of Socio-Economic Geography and Spatial Management of Adam Mickiewicz University in Poznań (Stryjakiewicz 2008a, 2008b; Stryjakiewicz et al. 2010; Stryjakiewicz, Męczyński 2010; Stryjakiewicz, Stachowiak 2010). They show that the proportion of employment in this sector in Polish cities can be as low as half the figure in many West European cities. Also the demands of social groups (made, e.g., at Cultural Congresses held in several Polish cities) are similar: they emphasise the need for preparing multi-year strategies of the development of culture (especially at the local level), greater social participation in preparing and executing a cultural policy, and transparent systems of financing and evaluating cultural activities. The concern is no longer only for higher inputs for the development of the cultural sector, but also for its socialisation (the inclusion of various social groups in the organisation of and participation in culture) and the modernisation of the entire process of culture management. In order for culture to be a real driver of social change, it is necessary to find an equilibrium between its public mission and commerce. In the Polish conditions, culture is largely the responsibility of self-governments of towns and regions. Self-governments spend five times as much means for cultural activity as the state. In the largest cities (Warsaw, Cracow, Wrocław, Poznań) the outlays for this purpose take up 3-4\% of their budgets, as against less than $1 \%$ going to culture from the state budget. It is therefore urgent to determine fields, forms and instruments of support for this sector.

The power of attraction of cultural industries and their development in specified places rests on different determinants than in the traditional branches. One of them is the formation of socalled creative clusters in the urban space. This, in turn, needs a new approach to be worked out in the domains of urban policy, regional policy, 
management, as well as architectural and town planning. Alas, as has already been mentioned, the awareness of the necessity of such changes among representatives of planning and decision-making practice has been relatively low in Poland so far. Cultural industries are treated fairly marginally also in education programmes. The need to fill in this education gap is the next most important reason for the organisation of the postgraduate studies discussed, especially that their subject matter covers two areas of instruction defined as being of key significance for the implementation of the Europe 2020 Strategy (2010):

- architecture, architecture and town planning, interior architecture,

- cultural industries, including education in plastic arts in the fields of TV image, film and photography.

In advanced countries, towns and regions treat the development of culture very seriously as a key area of the creative sector (and more broadly of the modern economy sector), a factor of growth in the quality of life of their residents, and a promotion of their areas. The cooperation and participation of local communities in culture has become an important goal of urban and regional development, while the use of up-to-date management instruments in this field is the aim of public authorities. Civic and commercial patronage reinforces the local cultural potential, stimulates cooperation, and causes the boundaries of activities conducted by local government units to be surpassed, which helps to break down barriers to wide access to culture. In this context, public administration faces a special task: it should create conditions for the preservation of the cultural heritage and support ventures involving its use in urban and regional development. The role of public administration should be to inspire and coordinate measures taken by museums, galleries and all kinds of institutions of culture, art and cultural tourism, all managed in a modern way. This should induce those entities to make a systematically ordered 'transformation', adjusted to their respective development goals, of the original output of modern culture, art and cultural heritage resources into suitable 'products' (services, material goods, complex service packets), and to address and supply them to various groups of end consumers of culture. Those rules and the experiences gained so far should be used in the practice of Polish public institutions, helping them to improve the efficiency of measures taken under development policy. A way to execute this task is through education that builds up the knowledge, skills and competence of both, present and future workers of those institutions, which is the principal goal of the postgraduate studies presented here.

\section{Programme and organisational assumptions of the syllabus of the studies}

The syllabus of the postgraduate studies $\mathrm{Cul}$ tural industries in the development policies of cities and regions was prepared as part of a broader application under the Human Capital Operational Programme worked out by Adam Mickiewicz University in Poznań. The application was a response to a competition announced by the National Centre for Research and Development in 2013 in connection with Priority IV: Tertiary Education and Science, Measure 4.3: Enhancing the didactic potential of universities in areas of key importance for the Europe 2020 Strategy, and it included a project entitled Integrated development programme of Adam Mickiewicz University in Poznań: Advanced technologies for the development of highly qualified personnel for the economy. Apart from the course under analysis, it also embraced launching three other kinds of postgraduate studies: Advanced materials and nanotechnology in practice, E-learning for the Polish school: implementation, management and service, and Legal-economic aspects of managing an enterprise. It also included scholarships for young doctors of information technology and the adjustment of selected subjects in this field to distance learning. The project was carried out at Adam Mickiewicz University with a financial support of the European Social Fund in the period 2013-2015.

In working out the programme, it was assumed that the postgraduate course of study Cultural industries in the development policies of cities and regions was intended to educate professional administrative staff and highly qualified managers prepared to direct and plan the development of towns and regions in the field of broadly understood culture. It was also assumed that effective and innovative management had to be connected with a skilful use of support for this kind of ac- 
tivity from national and European public means and with the ability to assemble public-private means. The graduates of Cultural industries in the development policies of cities and regions should be well prepared to devise a cultural policy at a regional and a local level, to manage cultural development programmes, and to initiate and conduct their own cultural ventures. Thus, the goal of the study must be education in breaking down barriers in the management of culture by stimulating 'good governance' type of cooperation in this field, i.e. cooperation of three sectors: public (mostly self-government), civic and private. Its foundation should be endowing the present and future public administration staff and cultural managers with the knowledge and skills necessary for conducting effective national and international cultural activities in the conditions of the market economy and European integration. The formation of managerial skills has become indispensable for effective work and activity in contemporary cultural life, administration and business, especially in preparing and executing cultural projects as well as in managing and financing them, in view of the new possibilities of international cooperation in culture.

In order to achieve the above goals, it was decided that the programme should be organised in modules. The theoretical assumptions of such an organisation can be found in Skinner's theory of programmed instruction $(1960,1971)$, Keller's and Sherman's conceptions of a personalised system of instruction, Miller's task analysis (Szafraniec 1994), and Bloom's taxonomy of educational objectives (Bloom et al. 1956). In Poland, an attempt was made to introduce a modular organisation of the higher education system during its latest reform, but with poor effects (Próchnicka et al. 2011). Such an organisation means that the entire programme consists of courses grouped into modules and follows the principle of combining academic knowledge, practical skills, and social competence. It was assumed that those involved in the instruction process in each course would include:

- academic teachers,

- practitioners working in fields that require the skills and competence being formed, and

- foreign experts representing both, European and world academic centres as well as practitioners.
The modular organisation of instruction allowed arranging the programme in accordance with the adopted plan to accommodate such domains as theoretical foundations, urban policy, regional policy, spatial development, and a verification of the effects obtained in knowledge, skills and competence from a European perspective. It should be emphasised that an advantage of a modular organisation is also full flexibility in making changes so as to adjust its content to corrections prompted by an assessment of its implementation.

The total number of teaching hours in the postgraduate course of study Cultural industries in the development policies of cities and regions is 255 . The instruction process is implemented during 14 Saturday-Sunday meetings taking place every two weeks from October to June. It also includes a week's practical placement in Brussels, which allows students to get acquainted with political determinants of the development of cultural industries in the EU member states and with good practices of EU towns and regions connected with the support for and management of those industries. In sum, half of the hours in the programme go to domestic practices $(32 \%)$ and classes with foreign experts and practitioners $(18 \%)$ directly connected with the sector of cultural industries, whose knowledge and experience significantly improves the quality of the instruction process by combining theory with practice. They represent the following institutions:

1. abroad:

- University of Birmingham (Great Britain),

- University of Warwick (Great Britain),

- University of Barcelona (Spain),

- School of Performance and Cultural Industries, University of Leeds (Great Britain),

- Institute of Geography, Hungarian Academy of Sciences (Hungary),

- Leibniz Institute for Regional Geography (Germany),

- Rem Koolhas Design Studio (The Netherlands),

- VanBerlo Eindhoven (The Netherlands).

2. at home:

- Warsaw University,

- Poznań Technical University,

- Institute of Sociology, Adam Mickiewicz University in Poznań, 
- Regional Observatory of Culture - AMU Research Centre,

- Chair of Regional and Social Geography, Łódź University (the project Development Strategy for Piotrkowska Street in Łódź, 2009-2020),

- Agency for the Development of Pomerania Creative Business Network in Gdańsk,

- Regional Policy Departament, Marshal's Office of Wielkopolska Voivodeship in Poznań,

- Projects Coordination Bureau, Poznań City Hall,

- Revitalisation Section, Development Department, Poznań City Hall,

- Concordia Design Centre in Poznań,

- Zamek (Imperial Castle) Cultural Centre in Poznań,

- TRAKT Cultural Tourism Centre in Poznań,

- Art Stations Foundation in Poznań.

The instruction programme also includes classes with academic teachers (35\%) experienced in conducting research on the significance of cultural industries in the development of towns and regions in Poland and Europe. What completes the programme is a practical placement abroad, in Brussels (25\%).

In terms of structure, the programme consists of five modules implemented simultaneously, with care taken to preserve the consistency of the whole material. Each module embraces a few courses ensuring the acquisition of knowledge, skills and competence through contact with representatives of the set of instructors mentioned earlier: academic teachers, practitioners, and foreign experts. In characterising the main assumptions of the modules, one should note their goals and structure adopted to ensure their achievement.

\section{Module 1: Cultural sector and creative industries: theoretical-methodological foundations}

The chief goal of the module is to present the terminology, theoretical conceptions and determinants of the formation of cultural industries and the creative sector, and their significance for the economic development of towns and regions. An analysis is also made of determinants of the development of the labour market of representatives of the so-called creative class in Poland and in selected European cities. Also discussed are problems and possibilities of cooperation of representatives of the cultural sector and creative industries with local and regional authorities in the light of national and European experiences. To accomplish those goals, the module is divided into three interconnected types of courses: theoretical, cognitive-comparative and practical. The first, theoretical, course - Theoretical conceptions and determinants of the development of the cultural sector and creative industries - is conducted by academic staff in classes that combine lectures with seminars. The second course, of a cognitive-comparative nature - Development of the creative sector in selected European cities - also combines elements of a lecture and a seminar, but is delivered by foreign experts on the development of the creative sector, including cultural industries. The classes are mostly conducted in English. The third course - Activity of public and private entities connected with cultural industries and the creative sector in Poznan - is practical in nature and takes the form of workshops conducted by representatives of institutions and firms belonging to the creative sector in places where this kind of activity is carried out. Thus, classes are held, e.g., in the Zamek Cultural Centre, Concordia Design, and Porta Posnania - the Interactive Centre of the History of Cathedral Island. To receive credit for the module, the student has to prepare an essay presenting a selected theoretical conception of the development of the creative sector and its verification on the basis of practical experiences from abroad or from Poland. Such a paper puts together the student's knowledge, skills and competence he or she has acquired in classes conducted as part of the three courses.

\section{Module 2: Cultural industries in urban policy}

The goal of instruction in this module is to show the role of cultural industries in the present-day development of Polish and European cities. It is divided into three courses. The first - Cultural industries in the European and the national urban policy - is intended to determine the position of cultural industries in the operation of a city and the strategic planning of its development, with the participation of public author- 
ities and the civic and private sectors. It takes the form of lectures by academic teachers with practical experience in strategic planning for the Poznań agglomeration who are also active in local government structures. The second course - Strategies and policies of cultural development in European cities - is also conducted in the form of lectures by an expert from abroad. Its target is to compare Polish and European experiences in the use of cultural industries in the strategic planning of urban development. The next course Management of urban cultural institutions - allows students to broaden their knowledge and skills in the organisation and execution of the activity of cultural institutions in the reality of urban governments in Poland. Classes are conducted by an academic teacher with practical experience who works in the Regional Observatory of Culture of the AMU Research Centre. The next two courses present case studies of the use of cultural industries in the process of change in the urban space and the activation of local urban communities. The first - Institutional milieu and the urban space in the development of cultural industries and the creative economy - presents the example of Piotrkowska Street in Łódź, classes being conducted by an academic teacher from Łódź University who is also head of the project Development Strategy for Piotrkowska Street in Łódź, 2009-2020. The other course - Culture as an instrument of activation of local urban communities - collects examples from Poznań and Warsaw and is conducted by an academic teacher from Adam Mickiewicz University in Poznań and a practitioner who also teaches at Warsaw University. To get credit for the module, the student has to prepare a semester paper in one of the three areas: cultural policy at an international scale (e.g. the European Union) describing a selected programme/initiative (e.g. a Community one) and its execution in a selected town (urban region); the cultural policy/strategy of a selected town (urban region) in any EU country; or an example or proposal of an interesting innovative cultural initiative/ venture in a selected town or its quarter. The paper should be inspired by the knowledge, skills and competence the student has acquired in the course of module classes.

\section{Module 3: Cultural industries in regional policy}

The chief goal of the module is to present the role of cultural industries in regional development processes, and especially in the formation of the economic base of growth poles and in creating conditions for the diffusion of development processes from growth areas into their immediate and more remote surroundings. The module is divided into six courses that can be grouped into theoretical (the first three) and empirical ones (the other three). During the first two: EU cohesion policy and Polish model of a development policy, given in the form of lecture by an academic teacher, students acquire and sort out knowledge concerning the basics of conducting a regional policy in Poland in the light of its ever-changing determinants. The third course, which is also a lecture given by an academic teacher - Cultural industries in regional policy - broadens their knowledge with information on the significance of cultural industries in the practice of present-day European cohesion policy. The remaining three courses have a practical character. This part of the module starts with the course Creative sector and cultural industries in programming the regional development of Wielkopolska voivodeship, conducted by the head of the Regional Policy Department of the Marshal's Office of Wielkopolska Voivodeship. Students are taught here how to use the acquired ordered and broadened knowledge, including the good practices they have learned about, in programming and taking intervention measures under cohesion policy that serve to reinforce cultural industries and their effect on development at the regional scale. The other two courses in the empirical part of the module are classic case studies based on the workshop technique. The first - Role of the creative sector and cultural industries in regional development: The case of the Creative Business Network project, conducted by the Agency for the Development of Pomerania, presents the example of Pomeranian voivodeship, and the other - Role of design in the development of the creative sector and cultural industries and its effect on regional development: The case of the North Brabant region, carried out by the trend-watcher VanBerlo Eindhoven, focuses on Dutch experiences. Credit for the module is given on the basis of a written final work, prepared individually or in a team, 
on a module-covered subject agreed upon with the tutor.

\section{Module 4: Cultural sector and creative industries in the formation of public spaces}

The goal of the module is to present theoretical, spatial and social foundations of the formation of public spaces and their activation through cultural sectors and creative industries. It is divided into three courses intended to teach the student to identify, define and delimit public spaces, to appreciate their culture-creating significance, their role in the functional-spatial structure of towns, and the socially activating and city-creating role of the cultural sector and creative industries in the formation of public spaces. Students also acquire the skill to make a critical analysis of how public spaces function and to formulate correct conclusions on the basis of the identified barriers to and potential for development connected with the introduction of creative functions of various types, scales and ranges. In classes conducted by academic teachers and practitioners in the form of workshops, students also develop social competence, like the skill to carry on open discussion, work in a group, present a project in public, and think in a creative way about the many aspects of public spaces. The first course - A friendly city, an active city, a creative city: the role and significance of urban public spaces - is theoretical and introductory in nature. However, what is characteristic of this module is that it is not limited to the transmission of knowledge since it combines lectures with indoor and field classes. The second course - Activating and culture-creating role of the creative sector in urban space - is strictly practical, mostly taking the form of indoor classes, workshops, seminars, and field classes. Involved in the didactic process are not only academic teachers, but also practitioners and foreign experts, including those from the Rem Koolhas Design Studio and the TRAKT Cultural Tourism Centre in Poznań. The entire third course - Implementation of the Creative Cities idea: good practices - is devoted to the presentation of examples of the idea of Creative Cities implemented in the public space. This is done by a practitioner - a worker of the Revitalisation Section of the Development Department of the Poznan City Hall. Given the specificity of the module, credit for it is given on the basis of a team project prepared by students, which is a test of their ability to apply in practice the theoretical knowledge acquired and their social competence of work in a group.

\section{Module 5: Placement in Brussels}

The chief goal of the module is to present the significance of European institutions in forming the assumptions of Community policies that determine the development of cultural industries in the member states. The stay in Brussels is also intended to make students acquainted with good practices of regions of the member states in creating conditions for the development of cultural industries, thus improving the efficiency of development-oriented intervention in the European Union at a variety of spatial scales (e.g. the Brussels Region, the Ile de France Region, the Stockholm Region, the Basque Country Region). During their stay in Brussels students visit the following institutions: the European Parliament, the Council of the European Union and its Secretariat, the Committee of the Regions, the Permanent Representation of the Polish Republic with the European Union in Brussels, the UNESCO Representation in Brussels, and Information Bureaux of selected regions of the member states. The placement programme is prepared and implemented in cooperation with the Information Bureau of the Wielkopolska Region in Brussels. Students get credit for the module on the basis of a paper (including a synthesis in Polish and English) on a concrete point in the placement programme, which they present in the Brussels group of colleagues. Besides, they also have to prepare individual written reports on the whole of their placement.

When planning rules of the completion of studies, it was decided to depart from the practice of preparing a traditional diploma work. To graduate from Cultural industries in the development policies of cities and regions, a student has to have credit for the individual modules and to pass a diploma exam. The exam consists of three questions that a commission asks on the set of topics students are given by the end of the first month of classes in the given instruction cycle. During the exam a student presents his or her portfolio (a novel form of the diploma work), which includes written works and/or projects established earlier 
with module tutors and for which he or she has earned credit.

In preparing the syllabus for Cultural industries in the development policies of cities and regions, it was assumed that it would run from 1 June 2013 to 31 May 2015 and would embrace two instruction cycles, 2013/2014 and 2014/2015. It was designed for people working in public administration and dealing primarily with the creative sector and its role in local and regional development, as well as for university graduates who want to build up their knowledge, skills and competence in this field to become more competitive on the labour market. A total of 48 students enrolled in the course. In the first cycle $(2013 / 2014)$ most of them $(60 \%)$ were graduates of first-cycle studies simultaneously attending the second cycle of Spatial Management. The structure of students in the second cycle $(2014 / 2015)$ had changed fundamentally. Most of them (80\%) were workers of cultural institutions and public administration responsible for programming and carrying out a development policy promoting, e.g., the use of cultural industries to reinforce the endogenous potentials of individual areas. This change should be regarded, on the one hand, as confirming the effectiveness of the marketing campaign and 'whispering marketing' conducted by the graduates of the first cycle, and on the other hand, as proof of a pressing need for education in cultural industries and their use in the development process that occurs in both, self-government administration and cultural institutions themselves.

\section{Evaluation of the educational process and corrective measures taken}

The planned and the implemented didactic processes were subjected to evaluation as foreseen by the formal procedures of the Human Capital Operational Programme competition, but first of all dictated by the wish to raise the quality of instruction and to prepare the second edition of study in the best possible way. To this end, an evaluatory meeting was organised with students of the first edition (2013/2014) during which a questionnaire interview was made to assess the most important elements of the teaching process. Its results provided a basis for corrective measures introduced into the syllabus in the second edition (2014/2015).

In general terms, the students assessed the study as good. What they considered its most important effects were the social skills and competence acquired. The lower assessment of the effects in the field of knowledge probably resulted from the fact that in the first instruction cycle there was a large proportion of students for whom some information coincided with what they were taught during the second-cycle classes they attended at the same time. What the respondents indicated as the greatest advantages of the educational offer were meetings with practitioners and visits in cultural institutions. Thus, the involvement of practitioners in the instruction process and the organisation of some classes in real-life professional milieux, both at home and abroad, were regarded as the basic advantages of the programme. What the students listed among its weak points were a too detailed discussion of some problems and several-hour meetings with foreign experts during which communication had to be in English, which in their opinion made them hard to follow. When asked to order the modules from most to least attractive, the respondents were unanimous: Placement in Brussels turned out to be the most interesting. The module placed at the other end of this scale was Cultural sector and creative industries: theoretical-methodological foundations, which had turned out to be the most difficult because of its strictly theoretical character. When making a detailed assessment of the individual modules, the respondents emphasised their advantages and deficiencies. Among the former they included the right sequence of the issues taught, a great number of examples, the possibility of making design works, attractive places where classes were conducted (cultural institutions, Brussels), and the charisma of some instructors. Drawbacks included too small a number of workshop hours, an often uninteresting way of conducting classes, especially theoretical ones, and too small a number of hours of design classes. On the basis of this assessment, the respondents formulated some general recommendations:

- to shorten the classes,

- to diversify classes in the various modules and reduce the size of blocks, 
- to improve the way in which visits of foreign experts in Poznań are used,

- to take greater care in selecting members of design groups so as to diversify them in terms of the occupational profile and the field of study completed, and

- to put greater emphasis on practice.

On analysis, the students' remarks provided a basis for changes introduced into the organisation of the instruction process implemented in the second cycle $(2014 / 2015)$. The most essential ones included:

- a correction of the syllabus on the basis of the evaluation results obtained, including a greater proportion of workshops and design classes,

- a replacement of some visiting experts and better use made of their stay in Poznan,

- a new organisation of classes in the first three modules by making their subject matters interconnected in a better way and by a greater diversification of instructors, and

- having classes planned for the entire academic year to make it easier for the participants to reconcile their occupational and private duties with class attendance.

The corrections were fully accepted by students of the second instruction cycle (2014/2015), who regarded them highly in terms of content and organisation. The results should allow achieving even better effects of education.

\section{Conclusions}

Culture and art as well as activities relying on those resources, including cultural tourism, have become an increasingly important factor of socio-economic development, both in the most advanced countries and moderately developed ones, like Poland. Growth in cultural industries is also one of the still underestimated ways of overcoming an economic recession because the demand for cultural products depends not only on the incomes of consumers, but also on their free time, value systems and lifestyles, and those have been undergoing an ever wider diversification stimulating the consumption of cultural goods. The demand for cultural products leads to the appearance of new workplaces in cultural industries, which is especially significant in re- gions going through processes of deep economic transformation and restructuring. The development of cultural industries requires competent and efficient management, not only in the ever more numerous commercial firms operating in this sector, but first of all in public (state, self-government and social) entities involved in cultural development, i.e. those financed largely from public means. This situation fully justifies the need for instruction highlighting the significance of those activities in developmental processes, an example of which is the presented programme of postgraduate studies.

The postgradual course of study Cultural industries in the development policies of cities and regions worked out and implemented by the AMU Institute of Socio-Economic Geography and Spatial Management has met with very great interest on the part of candidates, both those already employed in cultural institutions or public administration and those seeking their future jobs in such places. The chief strong points of this programme include:

- many fields of instruction resulting from the specific nature of the Spatial Management specialisation and covering theoretical foundations and determinants of development policies of cities and regions, including the determinants of physical planning;

- a transparent, modular arrangement of the content taught, on the one hand offering a diversified form of classes, and on the other involving many specialists from a given area of knowledge and skills;

- pragmaticity of instruction, corroborated by a very high proportion of practitioners involved in preparing and giving classes; and

- internationalisation of the programme following from the possibility of contact with international experts during workshops, with the placement in Brussels offering a verification of the knowledge, skills and competence acquired.

The experiences obtained and observations made by the participants of the presented programme of postgraduate studies fully recommend it for popularisation among higher schools interested in the development of this area of education. 


\section{References}

Bloom B.S., Engelhart M.D., Furst E.J., Hill W.H., Krathwohl D.R., 1956. Taxonomy of educational objectives: The classification of educational goals. Handbook I: Cognitive domain. David McKay Company, New York.

Boschma R.A., Fritsch M., 2009. Creative class and regional growth. Empirical evidence from seven European countries. Economic Geography 85 (4): 391-423.

Churski P., 2013. Modułowy program kształcenia - szansa na podniesienie jakości kształcenia na kierunku gospodarka przestrzenna (Modular programme of instruction: a chance to raise the quality of education in the Spatial Management field of study). In: Churski P., Kudłacz T. (eds), Gospodarka przestrzenna - doświadczenia i wyzwania procesu ksztatcenia. Biuletyn KPZK PAN, vol. 251, Warsaw: 9-23.

Churski P., Motek P. (eds), 2013. Przemysty kultury w polityce miast i regionów. Program ksztatcenia studiów podyplomowych (Cultural industries in the development policies of cities and regions. The syllabus of postgraduate studies). Institute of Socio-Economic Geography and Spatial Management, Adam Mickiewicz University, Poznań.

Europe 2020. The EU strategy for smart, sustainable and inclusive growth. Commission's Communication, COM (2005) 2020. 3 March 2010, Brussels.

Florida R., 2002. The rise of the creative class and how it's transforming work, leisure, community and everyday life. Basic Books, New York.

Florida R., 2005. Cities and the creative class. Routledge, New York.

Klasik A., 2010. Rola sektora kultury i przemystów kreatywnych $w$ rozwoju miast $i$ aglomeracji (Role of the cultural sector and creative industries in the development of cities and agglomerations). Uniwerytet Ekonomiczny, Katowice.

Próchnicka M., Saryusz-Wolski T., Kraśniewski A., 2011. Projektowanie programów studiów i zajęć dydaktycznych na bazie efektów kształcenia (Designing programmes of study and classes on the basis of educational effects). In: Kraśniewski A. (ed.), Autonomia programowa uczelni. Ramy kwalifikacji dla szkolnictwa wyższego. Project National Qualifications Framework in tertiary education as a tool for improving the quality of education, Priority IV PO KL, Measure 4.1., Sub-measure 4.1.3., Ministry of Science and Higher Education, Warsaw.

Skinner, B.F., 1960. Teaching machines. In: Lumsdaine A.A., Glaser R. (eds), Teaching machines and programmed learning. National Education Association, Washington.
Skinner B.F., 1971. Beyond freedom and dignity. Hackett Publishing Company, Indianapolis.

Stryjakiewicz T., 2008a. Regiony kreatywnej wiedzy - zarys międzynarodowego projektu badawczego ACRE (Creative knowledge regions: an outline of the ACRE international research project). In: Stryjakiewicz T., Czyż T. (eds), O nowy kształt badań regionalnych w geografii $i$ gospodarce przestrzennej. Biuletyn KPZK PAN, vol. 237: 129-145.

Stryjakiewicz T., 2008b. Rozwój sektora kreatywnego $\mathrm{w}$ regionach metropolitalnych (Development of the creative sector in metropolitan areas). In: Parysek J.J., Stryjakiewicz T. (eds), Region społeczno-ekonomiczny i rozwój regionalny. Bogucki Wydawnictwo Naukowe, Poznań: 105-119.

Stryjakiewicz T., 2010. Location factors of the creative and knowledge-intensive industries in European metropolitan regions. Geograficky Časopis 62/1: 3-19.

Stryjakiewicz T., 2011. Rola sektora kreatywnego w rozwoju miast i regionów (Role of the creative sector in the development of towns and regions). In: Marciniak K., Sikora K., Sokołowski D. (eds), Koncepcje i problemy badawcze geografii. Wyższa Szkoła Gospodarki, Bydgoszcz: 407-418.

Stryjakiewicz T., Kaczmarek T., Męczyński M., Parysek J.J., Stachowiak K., 2010. Polityka wspierania rozwoju sektora kreatywnego w poznańskim obszarze metropolitalnym na tle doświadczeń zagranicznych (Policy of support for the development of the creative sector in the Poznan metropolitan area in the light of foreign experiences). Bogucki Wydawnictwo Naukowe, Poznań.

Stryjakiewicz T., Męczyński M., 2010. Atrakcyjność poznańskiego obszaru metropolitalnego dla pracujacych w sektorze kreatywnym (Attractiveness of the Poznań metropolitan area to workers of the creative sector). Poznań: Bogucki Wydawnictwo Naukowe.

Stryjakiewicz T., Stachowiak K., 2010. Uwarunkowania, poziom i dynamika rozwoju sektora kreatywnego w poznańskim obszarze metropolitalnym (Determinants, level and dynamics of the development of the creative sector in the Poznań metropolitan area). Bogucki Wydawnictwo Naukowe, Poznań.

Szafraniec K., 1994. Projektowanie ksztatcenia i doskonalenia zawodowego dorostych opartego o koncepcje modutów kwalifikacyjnych. Ksztatcenie modutowe (Designing adult education and refresher courses based on the conception of qualification modules. Module-type of instruction). ZG ZZDZ, Warsaw. 